\title{
Encouraging Data-driven Environmental Protection Policy Making on Risk-based Licensing
}

\author{
$1^{\text {st }}$ Badrudin Kurniawan ${ }^{1}, 2^{\text {nd }}$ Meirinawati $^{2}, 3^{\text {rd }}$ Indah Prabawati ${ }^{3}$ \\ \{badrudinkurniawan@unesa.ac.id1, meirinawati@unesa.ac.id2,indahprabawati@unesa.ac.id3 \} \\ Department of Public Administration, Faculty of Social Science and Law, \\ State University of Surabaya, fish@unesa.ac.id ${ }^{123}$
}

\begin{abstract}
Indonesian government designs Bill Draft on Job Creation as strategic step becoming the Top Five World Economic Powers. The bill draft adopts Omnibus Law method. It used to replace and/or revoke provisions in a law, or to rearrange several provisions in a law into one law. Several groups considered it is going to threaten potentially environmental sustainability because it removes environmental permit. However, this draft requires also industries having a risk-based bussiness license. Before obtaining the license, certain industries have to undertake an environmental feasibility test. So far, environmental impact assessment has left many problems, particularly on data usage. Even though a more data-driven and empirical approach to environmental protection promise many benefits. So the study aims to scrutiny a data need on the process of publishing the license and how to meet it. This study uses library research approach. The result shows that risk-based business licensing need more data to produce good analysis. Moreover, the government should upgrade the data governance performance
\end{abstract}

Keywords: omnibus law, risk-based business license, data-driven policy making, data governance

\section{Introduction}

In early 2020, Indonesia government propose Bill Draf on Job Creation adopting omnibus law method. It promotes the government achieving their goal to increase rapidly economic growth. The government argues that it will be a strategic step for becoming Top Five World Economic Powers. Omnibus law or omnibus bill is simply defined as a method of deregulation. O'Brien and Bosc assert that several amendments to the Law were carried out through one Act in order to facilitate certain policies stipulated by the state [1]. Several certain policies are constituted by the draft include simplification of business licenses, requirements of investment, employment, convenience and protection of micro, small, and medium enterprises (MSMEs), ease of doing business, research support and innovation, government administration, imposition of sanctions, the land acquisition, government investment and projects and econonomic area [2].

Although Bill Draft on Job Creation has a role to elevate Indonesian economic growth but many group oppose this plan. They claim that this draft will create potentially social injustice and environmental degradation. Anggono states that omnibus law technique has several weakness such as (1) it tends to reduce the accuracy and caution in drafting the bill; (2) and it has the potential to exceed the provisions of the constitution due to reduced deliberation [3]. It 
is likely being occured because many issues regulated on one act. Hariadi Kartodihardjo, Professor of Forestry Policy at Bogor Agricultural Institute, regretted that the bill draft doesn't clearly mention local/customary communities access on forest resource management [4]. Executive Director of the Indonesian Center for Environmental Law (ICEL), Raynaldo Sembiring, criticized the contents of the draft regulation that the Environmental Permit is no longer valid as a requirement for a Business License [5]. Thus, this draft is considered to be accelerating environmental damage due to hinder monitoring and environmental law enforcement.

However, the government underline that the bill draft accomodating environmental protection aspect on business license. Environmental permit are indeed removed in the draft but private enterprises have still responsibilities to monitor and to manage environmental impact. It is embedded in risk-based business licensing. Risk-based business licensing is carried out based on stipulation business activity risk level. The determination of the risk level is carried out based on the calculation of the value of the hazard level and the value of the potential hazard. The hazard level assessment is carried out on the following aspects: (1) health; (2) safety; (3) environment; and/or (4) utilization of resources. Moreover the private enterprises have to conduct Environmental Impact Analysis (EIA) and Environmental Management EffortEnvironmental Monitoring Effort (EME) standards as one of requirements gaining business license.

The availability of data plays an important role in determining an accurate risk assessment and environmental impact analysis. Unfortunately, this is actually a weakness of the government, for example government doesn't have yet comprehensive data regarding carrying capacity. So it is feared that environmental risks and impact are not considered comprehensively and carefully [6]. In addition, many project proponents neglect the importance of data in the implementation of EIA [7][8]. Accordingly, this paper entitled Encouraging Data-driven Environmental Protection Policy Making on Risk-based Licensing. The study aims to provide recommendation for government to increase quality of environmental policy making.

\subsection{Literature Review}

\section{Data-driven Decision Making}

Ackoff argues that data, information, and knowledge form a continuum in which data, are transformed to information, and lastly to knowledge that can be considered to make decisions [9]. At the data level, the two relevant skills are "collect" and "organize". Information-level skills are "analyze" and "summarize". At the knowledge level, "synthesize" and "prioritize" are the skills seen as relevant [10].

The stakeholder must decide what data to collect and interrogate existing sources of data. After the data has been collected, it is necessary to organize the data systematically. The stakeholder then analyzes those data for informational purposes [10]. Several analysis technique are usually used such as longitudinal analysis, program evaluation, cost-benefit analyses; or root-cause analyses [11]. Regardless of the depth and breadth, there needs to be some sort of summarization of all the gathered information. To convert information into knowledge, stakeholders have to synthesize the available information. The final step is to prioritize the knowledge. Setting priorities often requires imparting a value judgment on the accumulated information and knowledge. Then decision is underlied by the knowledge. Decision's impact will become feedback for the whole process [10]. The following is a picture of framework for data-driven decision making. 


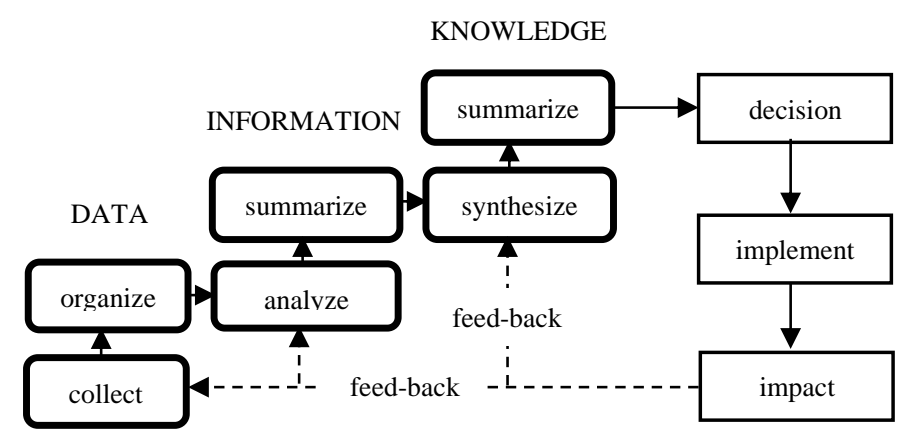

Fig.1. Framework for Data-Driven Decision Making

The most significant challenge of data-driven decision making is organizing their data in ways and into systems that make them accessible and query-able [11]. Secada [12] notes decision makers must have specific approaches when examining data, and they have to make the strategic and timely decision [12]. Sometimes the most persuasive data are not readily observed but are hidden in the sea of information we deal with every day. It necessary an appropriate analysis to reveal the data type. Detailed data and sophisticated analysis lead to new and important information [11].

\section{Risk-based Regulation}

Risk assessment for new bussiness is a part of adopting it. According to Black and Baldwin, risk-based regulation can be defined as an evidence-based tools benefiting resources based on the level of risk in accordance with a transparent, systematic, and defensible framework [13]. Thus, it depends upon high quality data, relevant assumptions and the quantity of information [14].

Black and Baldwin argue that a risk-based framework has five core elements in common. First, the objectives of the risk-based regulation. Secondly, what type of risks is it prepared to tolerate and at what level. Thirdly, it involves a risk assesment. Two broad categories of risks are identified: (1) inherent risks arising from the nature of the business activities and, in environmental regulations, their location; and (2) risk management and control, including compliance records. Fourth, regulators stipulate scores and / or ratings for companies or activities based on risk assessments. These scores may be broadly framed into three categories ("high", "moderate", or "low") or there may be a more detailed scoring system with five or more categories. Fifth, it provides a way to link organization and surveillance, inspection, and often enforcement resources to a risk score stipulated to individual companies or system-wide problems [13].

In addition, The UK Environment Agency uses the operational risk appraisal (Opra) to assess the risks that businesses generate to the environment. The assessment considers four attributes: type of activity carried out (attribute complexity), location of activities and sensitivity to pollution, types of pollutants (emissions) and operator performance in fulfilling permits and managing risks. Opra is also used to help decide the annual cost recovery rate for an operator based on the overall risk rating, or score, assigned to the operator. [15]. 


\section{Methodology}

This research aims to critize Bill Draft on Job Creation especially on clause that constitute the change of EIA process. This study describes data usage in EIA arrangement either before or after the change. Furthermore, the study points out the importance of the data quality. Therefore, to accomplish it, the authors decide to use secondary data only. This method can be grouped as a library research because using materials such as Bill Draft on job Creation, books, journals, proceeding, news articles as the main data source [16]. All materials are from various reliable sources. In addition, this type of research is able to facilitate various needs of researchers because it allows researchers to use components from other research methods.

Based on the type of data and analysis techniques, this study adopts a qualitative approach. Results are not obtained through statistical procedures or other computational processes. This approach requires the researcher to elaborate, categorize and connect the variables studied in a narrative [17]. Meanwhile, for data analysis, this study uses an interactive model. This research does not separate data collection and data analysis activities [18]. The results of temporary data analysis were used by researchers as the basis for further data collection.

In terms of research objectives, the research includes applied research. Research is oriented towards the practical application of science and the importance of real problems in society [19].

\section{Finding and Discussion}

\subsection{Risk-based Business Licensing in Bill Draft on Job Creation}

The implementation of risk-based business licensing is one of attempts to build an ecosystem supporting investment and business actitivites. The other efforts include simplification of the basic requirements of business licensing and the land acquisition; simplification of sector business licensing; and simplification of investment requirements. It is carried out based on stipulation business activity risk level [20].

The determination of the risk level is conducted based on the calculation of the value of the hazard level and the value of the potential hazard. The hazard level assessment is carried out on the following aspects: (1) health; (2) safety; (3) environment; and/or (4) utilization of resources. It considers several aspects namely type of businesses; criteria of businesses; business location; and limited resources. The value of the potential hazard is grouped into four categories such as (1) never happen; (2) rarely happening; (3) ever happened; or (4) often occur. Finally, those two assessment divide the risk level of business activity into three categories: low risk; medium risk; and high risk [20].

The division of risk level becomes a reference in determining the intensity of supervision. The authority of supervision is hold by central government. The government carries out strict supervision and inspection of high-risk business activities. [21]. Further provisions regarding risk-based business licensing and the monitoring procedure are regulated by a government regulation [Bill Draft on Job Creation].

All business activities, low-medium-high risk level, should have risk-based business license. However any type business should take different way to get it. Low risk level businesses are able to gain the license only by registering their business to government. They are not necessary to fulfil environmental management standard or to conduct Environmental Impact Assessment (EIA). Then, medium risk level businesses have to meet environmental 
management standard first and then be able to obtain the license. Lastly, before having the license, high risk level businesses must follow the environmental feasibility test [21]. The authority of undertaking the test is hold by central government. Central government appoint institution or individual who have been certified to carry it out. Further provision regarding the environmental feasibility test will be constituted by Government Regulation [20].

Environmental Impact Assesment (EIA) document becomes a foundation of the environmental feasibility test. The document contains several points for instance, the business impact, recommendation from impacted community and environmental management plan. Those who arrange the document had to be certified. EIA document is carried out by involving people who are directly affected by the business activities. If there is micro and small enterprises decided having high risk level, central and local government will help them for conducting EIA [20].

However, so far many problems faced when setting out the EIA document. It is consist of manipulated result of public consultation, only inviting impacted people who support the business joining in public consultation, bribe, extortion etc. The EIA document has beed made but it is not implemented [22]. Additionally certain study draws it in issue of data usage. Survey result points outs that several EIA documents created by only copying from the EIA document from other business [8].

\subsection{Data Requirements and the Challenges of Data Governance}

However not only in Indonesia, EIA implementation in developing countries in Asia faces data-related problem as well. One of the problems is an inadequate baseline data upon which to base analyses [23]. Moreover, there are many problem of data governance such as data are often collected on an irregular basis, available only in paper-based formats and in the national language, manipulated incompletely or clearly, or may not exist at all. Additionally, access to data can be a matter of power and is dependent on the existing connection. Decision-makers and administrative personnel in developing countries are often unfamiliar with ex-ante impact assessment metohods or with choices about how to understand and interprete the concept of sustainability [24].

In Indonesia, limited availability of environmental data, even on basic environmental criterion, which increases the time and cost required for an EIA study [25]. The main problem with data collection is that the time series data set is not available; data are often incompatible they were collected using a different methodology, not digitized (eg maps) and, if digitized, saved in a different format; different institutions (or even different body parts) often produce contradictory data; and often there are no free copies of related reports or hard copy data - it will take a long time to copy and gather this information. Forestry, agricultural, meteorological and hydrological data are generally considered the most difficult to obtain [26].

EIA should be an integral part of the project feasibility study. The project feasibility study has to include a detailed assessment of notable impacts, including collection of basic information; forecasting and quantification of effects; and EIA review by review bodies (by public and independent experts) [23]. Therefore data availability and data usage for crafting the EIA document has a vital role. An inadequate baseline data affects the impact projections making. Consequently, extensive baseline data must be gathered. This is perhaps the single most expensive and time consuming EIA implementation [23]. Unsufficient impact projection making will influence an inappropriateness of decision making as well. Thus strategy of waste management can not meet the real problem.

In Bill Draft on Job Creation regulates about risk assessment also. This assessment needs amount of data, indeed. First, the availability of data to measure the impact of industrial 
activities on health, safety, the environment and natural resources. Second, the data on the classification of the carrying capacity of regions in Indonesia which is a determining factor for environmental risk. Social and cultural aspects must be considered in making this classification [27]. Risk-based business licensing increases the need for adequate environmental data. The governments have to address this problem in order to determine accurately the business risk. The bias result of risk assessment may create useless decision or even the environmental destructive action.

Both risk assessment and environmental feasibility test should be supported by good quality data. The quality data is related to several aspects such as accuracy, availability, completeness, consistency, and timeliness of data and the limitation of errors due to data inconsistencies [28]. Thus, in this term, environmental protection can be realized only if the government improve or increase the performance of data governance. Data governance is the exercise of authority and control over the management of data [29].

Lack of data governance generates low quality data. This problem may emerge due to the limited number of skilled personnel and / or technology which is then linked to capacity building and funding [30]. In addition, Paskaleva et al argue that stakeholder engagement in a collaborative process will generate and use the required data. It can be considered at a high level transformation because it requires transformations in internal and external relationships and structures [Paskaleva et al, 2017]. Those two definitions frames data governance is not only government body issue but also the issue of collaboration between government and other actors. Thus, the suficient of data can be accomplished only by collaboration among actors. Good analysis of business risk and business impact will be happened if there is collaborative process in supply the data.

Risk-based business licensing should be promoted by data governance. Government has high responsiblity to create the good one. The data governance leader is responsible for day-today management of the data governance program. The leader provides guidance on the design, transmission and maintenance of data and oversees data policy compliance. In addition, the leader coordinates duties for the data manager and provides periodic reports on data governance performance [28].

\section{Conclusion}

Indonesian government crafts Bill Draft on Job Creation to increase rapidly economic growth through accelerating economic investment. It adopts omnibus law method. Consequently, it changes several articles in Act on Environmental Protection and Management, especially on environmental permit issue. This sort of license is erased. However the government still make an effort for protecting the environment by regulating risk-based business licensing. Nevertheless, so far the government faces the problems to arrange a proper environmental assessment analysis. Whereas in this bill draft government is required a risk assessment as well. This activity highly needs a good quality of data. But to date, government shows the weak performance of data governance. Encouraging data-driven environmental policy making strongly needs the support of good data governance. Thus, nowadays Indonesia government should be able to meet the challenges for achieving good environmental quality. 


\section{References}

[1] A. O'Brien \& M. Bosc, eds, House of commons procedure and practice, 2nd ed. House of Commons \& Éditions Yvon Blais, Canada, 2009

[2] A. Hanggono, Perizinan Berusaha Berbasis Risiko: Penerapan Risk Based Approach (RBA): Kluster: Penyerhanaan Perszinan Berusaha. Directorate general of marine space management. Presentation materials, 2020

[3] B. D. Anggono, Omnibus law as a technique for formation of law: opportunity for adoption and it's challenges in Indonesia's legilation system. Jurnal Rechtsvinding: Media Pembinaan Hukum Nasional, 9, 12020.

[4] A. Lusia,"RUU Cipta Kerja Dinilai Ancam Masyarakat dan Lingkungan, Apa Kata Mereka?", 2020. [online]. Available: https://www.mongabay.co.id/2020/02/20/ruu-cipta-kerja-dinilai-ancammasyarakat-dan-lingkungan-apa-kata-mereka/. [Accessed: 7-Sep-2020].

[5] M.J. Rizki,"RUU Cipta Kerja dan Risiko Pengabaian Kerusakan Lingkungan Hidup“, 2020. [online]. Available: https://www.hukumonline.com/berita/baca/lt5e466f1fc768f/ruu-cipta-kerja-dan-risikopengabaian-kerusakan-lingkungan-hidup/. [Accessed: 14-Feb-2020].

[6] Indonesian Center for Environmental Law (ICEL), Pelemahan Instrumen Perlindungan Lingkungan dan Pengelolaan Lingkungan Hidup dalam RUU Cipta Kerja, ICEL: South Jakarta, 2020

[7] S.P. Hadi, Mengapa Banyak Proyek Tanpa AMDAL?, in Bunga Rampai Manajemen Lingkungan, Yogyakarta: Thafa Media, 2014

[8] Indonesian Center for Environmental Law (ICEL), Kertas Kebijakan: Mendorong Kebijakan Pemberian Informasi Lingkungan secara Proaktif oleh Badan Lingkungan Hidup Daerah, ICEL: South Jakarta, 2015

[9] R. L. Ackoff, From data to wisdom. Journal of Applied Systems Analysis, 16, 3-9, 1989

[10] E.B. Mandinach el al, A Theoretical Framework for Data-Driven Decision Making, Paper presented at the annual meeting of AERA, San Francisco April 9, 2006

[11] P.A. Streifer, Tools and Techniques for Effective Data-Driven Decision Making, Scarecrow Education: Maryland, 2004

[12] Secada, W. (2001, Spring). From the director. Using data for educational decision making. Newsletter of the Comprehensive Center-Region VI, 6, 1-2.

[13] J. Black and R. Baldwin, 2010. Really responsive risk-based regulation. Law \& Policy, 32, 2, 181 213.

[14] S.M.L. Bostock and B.M. Hutter, 2008. Reforming regulation of the medical profession: The risks of risk-based approaches. Health, Risk \& Society, 10, 1, 69-83.

[15] D. Giddens, Environmental Risk Management and Assurance, in Developments in Environmental Regulation:Risk based Regulation in the UK and Europe, London: Palgrave Macmillan, 2018

[16] Y. Wahyudin, "Humanistic Learning Theory of Carl Ransom Rogers and Its Implications for Teaching Methods of Islamic Education,” State Islam. Univ. Sunan Kalidjaga, 2009.

[17] A. Strauss, Basics of Qualitative Research: Procedures and Techniques. Yogyakarta: Pustaka Pelajar, 2009.

[18] B. Bungin, The Philosophical and Methodological Understanding towards Model Application Mastery. Jakarta: Rajawali Press, 2012.

[19] S. Bartolini, "Pure and Applied Research: Striking a Balance," 2011.

[20] Bill Draft on Job Creation

[21] Secretary General of Ministry of Environment and Forestry, RUU Cipta Kerja Bidang Lingkungan Hidup dan Kehutanan, It is presented at National Meeting of Environment and Forestry, Yogyakarta February 27th-28th, 2020

[22] H. Kartodihardjo, Merangkai stanza lagu kebangsaan. Bogor: Forest Watch Indonesia, 2018.

[23] B. Lohani et. al., Environmental Impact Assessment for Developing Countries in Asia, Vol. 1 Overview, Asian Development Bank, 1997

[24] E. F. Lambin, H. J. Geist, E. Lepers, Dynamics of land-use and land-cover change in tropical regions. Annual Review of Environment and Resources 28, 205-241, 2003. 
[25] T. Gore and T.B. Fischer, 2014. Uncovering the factors that can support and impede post-disaster EIA practice in developing countries: The case of Aceh Province, Indonesia. Environmental Impact Assessment Review, 44, 1055-1066.

[26] J. Dusik, SEA as a dialogue and planning support tool: Lessons from pilot projects in Indonesia, Indonesia-Denmark Environmental Support Programme, Phase 2, Component 1, 2010, Jakarta.

[27] H. Kartodihardjo,"Lemahnya Proteksi Lingkungan dalam RUU Cipta Kerja“, 2020. [online]. Available https://www.forestdigest.com/detail/685/lemahnya-proteksi-lingkungan-dalam-ruu-ciptakerja. [Accessed: 18-Sept-2020]

[28] R. Abraham, J. Schneider, J. V. Brocke, Data governance: A conceptual framework, structured review, and research agenda. International Journal of Information Management, 49, 424-438, 2019.

[29] DAMA International, The DAMA guide to the data management body of knowledge, New Jersey, Technics Publications, LLC, 2009.

[30] A. Susilowardhani, The Potential of Strategic Environmental Assessment to Address The Challenges of Climate Change to Reduce The Risks of Disasters: A Case Study From Semarang, Indonesia. Procedia-Social and Behavioral Eciences, 135, 3-9, 2014.

[31] K. Paskaleva et al, Data governance in the sustainable smart city, Informatics, 4, 41, 1-19, 2017 